Valuch, Tibor. "Correction to: Valuch, Tibor. "Following the Life Stories of Participants in the 1956 Hungarian Revolution." Hungarian Cultural Studies. e-Journal of the American Hungarian Educators Association, Volume 9 (2016) DOI: 10.5195/ahea.2016.253." Hungarian Cultural Studies. e-Journal of the American Hungarian Educators Association, Volume 10 (2017) DOI: 10.5195/ahea.2017.272

\title{
Correction to: Valuch, Tibor. "Following the Life Stories of Participants in the 1956 Hungarian Revolution." Hungarian Cultural Studies. e-Journal of the American Hungarian Educators Association, Volume 9 (2016) DOI: 10.5195/ahea.2016.253
}

Tibor Valuch, Hungarian Academy of Sciences valuch63@gmail.com

Abstract: The dates next to the names of two interviewees, Imre Lázár and Zoltán Mervó, were shown incorrectly. The original article can be found via the DOI:

http://dx.doi.org/10.5195/ahea.2016.253

\section{Erratum}

Page 183: Imre Lázár (b. 1935) was changed to Imre Lázár (1935-2016) and Zoltán Mervó (1935-2016) was changed to Zoltán Mervó (b. 1935).

\section{Full Text Original Article}

http://dx.doi.org/10.5195/ahea.2016.253 